\title{
Science Process Skills to Facilitate the Achievement of Students' Learning Outcomes
}

\author{
Rafiatul Hasanah \\ Institut Agama Islam Negeri Jember \\ Jember, Indonesia \\ Rafiatul.hasanah@gmail.com
}

\author{
Yuni Sri Rahayu \\ Universitas Negeri Surabaya \\ Surabaya, Indonesia \\ yunirahayu@unesa.ac.id
}

\author{
Laily Yunita Susanti \\ Institut Agama Islam Negeri Jember \\ Jember, Indonesia
}

\begin{abstract}
This study aimed to describe the effect of science process skills-based learning in facilitating the achievement of student learning outcomes in the topic of carbohydrate metabolism. The research design used was pre-experimental one group pretest-posttest design. Trials were conducted on 30 students of SMAN 1 Tarik, Sidoarjo. The results of this study consists of 3 components, which includes the results of academic learning both product (material / concept) on LP1, process (integrated and basic science process skills) on LP2-01 and LP202 as measured by written test, as well as attitudes on the observation sheet. The result of the research showed that the science process-oriented learning process can improve the students' understanding based on the result of the preliminary and final test which has increased the proportion of the correct answer both on the test in the product LP and the result of the affective level of the students character and social skill was very high. Based on the results of this study, it can be concluded that the science process skills can be used to facilitate the achievement of students' learning outcomes in the topic of carbohydrate metabolism.
\end{abstract}

Keywords-Science process skills; learning outcomes; carbohydrate catabolism.

\section{INTRODUCTION}

Biology that is a part of science is not only a collection of concepts, facts or principles but also a process of discovery. It is like the demands set forth in the content standard that through biology education is expected to be a vehicle for learners to learn about themselves and the environment, as well as the prospect of further development in applying it in everyday life. Biology learning should be conducted in scientific inquiry to cultivate the ability to think, work and be scientific and communicate it as an important aspect of life skills. Therefore, biology learning in SMA / MA emphasizes the provision of direct learning experiences through the use and development of process skills and scientific attitudes. In the curriculum of SMA / MA, Core competence provides an overview of the main competencies grouped into attitudes, knowledge, and skills (affective, cognitive, and psychomotor aspects) that learners should learn for a level of school, class, and subject, and basic competencies contains competencies consisting of attitudes, knowledge, and skills sourced from core competencies that must be mastered by learners [1].

This is in accordance with Carin [2] who explains that there are 3 main components in the nature of science learning. These components include scientific products, scientific processes, and scientific attitudes. Scientific products include facts, concepts, principles, laws, and theories. Scientific process in the form of methods, steps, ways of work or something to be done and researched to gain knowledge or explanation of natural phenomena through the skills of finding, among others: observing, measuring, classifying, communicating, defining, formulating hypotheses, interpreting data, analyzing data, designing and conducting experiments. While the scientific attitude is the attitude that must be possessed by a person to perform the scientific method. Scientific attitudes include curiosity, objective, honest, proven, responsible, accepting differences, cooperative, and representative. The components of the scientific process are better known as the science process skills. Karsli, et al. [3] suggest that through the skill of science process skill can give a big influence on the development of higher mental process ability like critical thinking and decision making. In addition, implementation of science process skills can also facilitate student to improve their literacy skills [4].

Science Process skills that must be mastered by high school graduates include the ability to observe, to make hypotheses, to use tools and materials properly and correctly with always considering safety procedures, asking questions, classifying and interpreting data, and communicating orally or in writing, digging and sorting out relevant factual information to test ideas or solve everyday problems. According to Raufl, et al. [5], the science process skills can be divided into 2 categories, namely basic and integrated science process skill. In teaching science process skills, teachers act as 
facilitators who make plans and provide learning activities that support science process skills-based learning [5].

Given the demands of Depdiknas, it needs an effort to enable students to understand and apply the steps of process skills. For students in some schools, these skills are new. For that reason, direct instruction is one of the models that can be applied in training process skills. According to Kardi and Nur [6], the direct teaching model is a specially designed model for developing student learning about well-structured procedural knowledge and declarative knowledge. Given process skills are procedural knowledge, they are suitable to be taught through direct instructional models. According to Wenno [7], the implementation of the direct teaching model can increase students' achievement in science learning.

Metabolic material that is taught in grade XII SMA / MA, has a knowledge aspect in KD: (3.4) Describe the process of carbohydrate catabolism and anabolism. The material is an abstract concept of biology, which, in its teaching, requires not only the understanding of concepts through lectures as is often done, but also requires an emphasis on the provision of direct experience. In order for students to find and obtain the concept/facts independently and can apply the concept in their daily life in accordance with the demands of the Ministry of National Education. One of them is by using the science process skills with the direct teaching model, to teach the skill component of the process step by step. The choice of the direct teaching model is also due to the research findings from Foulds and Rowe [8] that over the long term, it has been found that science process skills can be successful when taught and guided by the teacher before the students do or practice independently.

Based on the above discussion, the researcher tries to develop a learning device which contains the material or concept as well as to train the science process skill in the metabolism concepts of class XII SMA / MA to facilitate the achievement of students' learning outcomes.

\section{METHODS}

This study used a pre-experimental research design that is "one group pretest-posttest design" [9]. The study design is described as follows:

$$
\mathrm{O} 1 \rightarrow \mathrm{X} \rightarrow \mathrm{O} 2
$$

Note:

$\mathrm{O}_{1}=$ Pretest, to know the students' mastery of the concept before treatment

$\mathrm{X}=$ treatment with the implementing of learning devices based on science process skills using the direct teaching model

$\mathrm{O}_{2}=$ Posttest, to know the students' mastery of concept after the treatment

The subjects of this study were 30 students of grade XII of SMAN 1 Tarik Sidoarjo. Data collection techniques that used was test and observation methods.

\section{RESULT AND DISCUSSION}

The results of this study include 3 components in accordance with the nature of science learning, which includes the results of academic learning both product (material / concept) on LP1, process (skill of integrated and basic science process) on LP2-01 and LP2-02 as measured by written test, as well as attitudes (character and social skills) on the observation sheet.

\section{A. Mastery of Learning Outcomes}

Mastery of students' learning outcomes are reviewed individually called individual mastery. Mastery of individual student learning outcomes seen from the results of three kinds of tests, namely product cognitive tests, basic processes and integrated processes. Mastery on product learning outcomes using Assessment Sheet 1: Products. The result data from pretest was found that none of the students were pass, with $0 \%$ average of mastery learning (Table 1). This is because students have not been given knowledge about the concept of carbohydrate metabolism (anabolism and catabolism), so the students' knowledge of the concept is still low.

The result on the posttest was 25 students pass and 5 students are not pass, the overall percentage of the classical mastery learning was $83.33 \%$, which means classical mastery over $75 \%$ (Table 1). This results showed that in terms of product cognitive ability, learning devices such as the use of textbooks, student worksheets and media power point and flash media macros can help students in understanding the concept of carbohydrate metabolism, so the most students can be pass on mastery learning.

TABLE I. The Results of Students' Mastery Learning Outcomes

\begin{tabular}{|c|c|c|c|c|c|c|c|c|c|c|}
\hline \multirow[t]{2}{*}{$\begin{array}{l}\text { Lear } \\
\text { ning } \\
\text { Outc } \\
\text { omes }\end{array}$} & \multicolumn{2}{|c|}{$\begin{array}{l}\text { Average } \\
\text { Score }\end{array}$} & \multicolumn{2}{|c|}{$\begin{array}{c}\text { Average } \\
\text { of } \\
\text { Indicator } \\
\text { Mastery } \\
(\%)\end{array}$} & \multirow[t]{2}{*}{$\underset{\text { I }}{\text { AS }}$} & \multirow[t]{2}{*}{$\begin{array}{l}\text { Sensiti } \\
\text { vity }\end{array}$} & \multicolumn{2}{|c|}{ API } & \multicolumn{2}{|c|}{$\begin{array}{c}\text { Indicato } \\
\mathbf{r} \\
\text { Mastery }\end{array}$} \\
\hline & P1 & $\mathbf{P 2}$ & P1 & P2 & & & P1 & P2 & P1 & P2 \\
\hline LP 1 & $\begin{array}{r}7, \\
52\end{array}$ & $\begin{array}{l}80 \\
32\end{array}$ & 0 & $\begin{array}{l}83 \\
33\end{array}$ & $\begin{array}{c}0,7 \\
2\end{array}$ & $\begin{array}{l}\text { Sensiti } \\
\text { ve }\end{array}$ & $\begin{array}{c}0,1 \\
2\end{array}$ & $\begin{array}{c}0,8 \\
3\end{array}$ & NP & $\mathrm{P}$ \\
\hline $\begin{array}{c}\text { LP } \\
2-01\end{array}$ & $\begin{array}{l}2, \\
33\end{array}$ & $\begin{array}{c}84, \\
2\end{array}$ & 0 & 90 & $\begin{array}{c}0,8 \\
4\end{array}$ & $\begin{array}{l}\text { Sensiti } \\
\text { ve }\end{array}$ & $\begin{array}{c}0,0 \\
4\end{array}$ & $\begin{array}{c}0,8 \\
5\end{array}$ & NP & $\mathrm{P}$ \\
\hline $\begin{array}{c}\text { LP } \\
2-02\end{array}$ & $\begin{array}{l}3, \\
47\end{array}$ & $\begin{array}{l}75, \\
34\end{array}$ & 0 & $\begin{array}{l}73, \\
33\end{array}$ & $\begin{array}{c}0,8 \\
4\end{array}$ & $\begin{array}{l}\text { Sensiti } \\
\text { ve }\end{array}$ & $\begin{array}{c}0,0 \\
2\end{array}$ & $\begin{array}{c}0,8 \\
4\end{array}$ & NP & $\mathrm{P}$ \\
\hline
\end{tabular}

The LP results of this product also found that all indicators are complete (mastery by students), this can be seen from the average proportion of the initial test of 0.12 with the average proportion of the final test of 0.83 . The increasing of proportion items showed that the implementation of science process-oriented learning devices also greatly assist the students in understanding the theories or concepts being taught. The similar results was showed by Abungu [10] who states that science process skills can improve students' ability to understand a concept better than implementing other learning processes. 
The average of the sensitivity index was 0.72 with the category of sensitive, which means that the problem is sensitive to learning. Matery learning results was measured with the using of Assessment Sheet 2-01 (LP 2-01) : Integrated Process. Results obtained from the pretest that none of the students was pass, with the average of mastery learning of $0 \%$. This is because students have never practiced integrated science process skills either on carbohydrate metabolism material or on other subject matter, so the student scores in this initial test were very low. The different results were shown on the posttest that were 27 students pass and 3 students are not pass, the overall percentage of classical mastery is $90 \%$.

The high percentage of classical mastery was obtained because in the learning process almost all students were interested in the activity that was already prepared by teacher. Many students were actively involved in the learning such as practicum activities. In practicum activities, students are taught to perform integrated science process skills, so they could practice their science process skills. Through practicum activities students also find it easy to learn abstract concepts (photosynthesis and respiration) to be more concrete. This is in accordance with the results of the study by Ango [11] that practicum activities or work exercises in the laboratory can assist students in diverting abstract concepts into real experiences. Mastery of learning outcomes on integrated process tests relates to the high student activity in performing the science process skills, as well as the results of questionnaire responses of students who said that they were interested in the learning of carbohydrate metabolism material using science process skills based learning. The interest of students on the learning process caused students to be motivated to study. The concepts that have been obtained can be easily understood and more embedded in the memory of students. This is in line with the opinion that with motivated learning can improve student learning outcomes ([12]; [13]; [14])

In the results of the LP, this integrated process also found that all indicators are completed, this can be seen from the average initial test proportion of 0.04 and the average proportion of the final test of 0.85 . These data show that there is an increase in the proportion of correct answers after the students follows the learning activities that use learning devices based on science process skills. Therefore, the use of learning devices can help students in the improving of science process skills, especially integrated process skills. The average value of the sensitivity index was 0.84 with the sensitive category. This indicates that the item is sensitive to learning, meaning that this developed problem can provide information that the measurement results obtained is the result of the learning given

Mastery of basic learning outcomes using Assessment Sheet 2-02 (LP 2-02): Basic Process. Results obtained on the pretest that none of the students who pass, with $0 \%$ average mastery. This is also because students have never practiced basic science process skills in carbohydrate metabolism materials or on other subject matter, so the student scores in this initial test are very low. Results on the posttest there are 22 students who pass and 8 students that were not pass, the overall percentage of classical mastery only amounted to $73.33 \%$. The lack of mastery in LP 2-02 was due to some students being unenthusiastic, uninterested, and unmotivated in practicing basic process skills. The low motivation of student learning was caused by unmotivated students. In the learning students activity was only answered the question in the students' worksheets without any practice, so the students feel bored, saturated and feel monotonous. The average preliminary test proportion shows 0.02 and the average proportion of the final test is 0.84 . From the data shows there is an increase in the proportion of correct answers after the students follow the learning activities that use learning tools oriented process skills, meaning that the use of learning tools can assist students in improving process skills, especially basic process skills. The average value of the sensitivity index is 0.84 with the sensitive category.

Broadly speaking, it is found that science process skills can improve student learning outcomes both products and processes. These results are almost identical to some of the results of the study by Aktamis and Ergin [15] which concluded that students who received skills training in the science process were more successful than students who received traditional training. The results of his research indicate that science skill givers improve students' academic achievement. Haryono [16] also states that science process skills-based learning model is significantly effective for improving the ability of students' science processes and science learning outcomes that include mastery of concepts, processes and attitudes. Mahsul [17] also states that learning based science process skills that taught by direct learning model can complete the objectives of product learning and student completeness in a classical manner. The same statement was declared by Haryati, et al.[18] that the direct learning model can improve the science process skills as well as the students higher order thinking skills.

\section{B. Affective Observation}

Observations on the affective domain that includes character behaviors and social skills are performed at each meeting. on the assessment of the character of accuracy, honesty and cooperation in a row obtained the average score of $90.00 ; 89,17$ and 90,00 (Table 2), where the three are in very high category.

TABLE II. The Results of Character Behaviors Observation

\begin{tabular}{|c|c|c|c|}
\hline \multirow{2}{*}{ Score } & \multicolumn{3}{|c|}{ Characters } \\
\cline { 2 - 4 } & Accuracy & & Accuracy \\
\hline Score Average & 90,00 & 89,17 & 90,00 \\
\hline $\begin{array}{c}\text { Average of } \\
\text { Category }\end{array}$ & Very high & Very high & Very high \\
\hline
\end{tabular}

In social skills that contribute ideas / opinions, be a good listener and appreciate the opinions of friends in a row obtained the average score of $89.38 ; 91.04$ and 89.58 (Table 
3 ), where the three are in very high categories. This suggests that the use of learning tools oriented process skills that involve student interaction in learning can improve the attitude of character and social skills of students during learning. During the learning activities, teachers emphasize students to perform the character and process skills in each phase / learning steps (in accordance with the developed of lesson plan). This reasoning is also reinforced by the assertion from Yara [19] who states that students' attitudes whether character or social skills are strongly influenced by the teacher's attitudes and the learning model used during the lesson.

TABLE III. The Results of Social Skills Observation

\begin{tabular}{|c|c|c|c|}
\hline \multirow{2}{*}{ Score } & \multicolumn{3}{|c|}{ Social Skills } \\
\cline { 2 - 4 } & $\begin{array}{c}\text { Contributing } \\
\text { Ideas/Opinions }\end{array}$ & $\begin{array}{c}\text { Be a good } \\
\text { listeners }\end{array}$ & $\begin{array}{c}\text { Appreciate the } \\
\text { opinion of } \\
\text { friends }\end{array}$ \\
\hline Score Average & 89,38 & 91,04 & 89,58 \\
\hline $\begin{array}{c}\text { Average of } \\
\text { Category }\end{array}$ & Very high & Very high & Very high \\
\hline
\end{tabular}

Through the inculcation of character behaviors and social skills in learning activities in schools was aimed for students to apply the scientific attitude in everyday life when interacting with the environment. The results of the study by Suyanto [20] convey that with the education of character and social skills applied systematically and sustainably, a child will be emotionally intelligent. This emotional intelligence is an important provision in preparing children for the future because one will find it easier and more successful to face all kinds of life challenges, including the challenge of academically successful. The application of these affective / scientific attitudes in the objective of biology learning is that learners have the ability to cultivate a scientific attitude that includes honest, objective, open, tenacious, critical and can cooperate with others. It is also stated by Carin [2] that one component in biology is scientific attitude.

\section{CONCLUSION}

Based on the results and discussion of this research that has been described previously, it can be concluded that (1) Student learning outcomes after following a science process skills-based learning process can improve students' understanding seen from the results of preliminary and final test that has increased the proportion of correct answers either on the test in LP product or process; (2) The affective level of character and social skill of the students in the learning activity using the learning devices which based on science process skill is very high.

\section{SUGGESTION}

Based on the conclusion, the researcher suggests: (1) The learning process by implementing the learning devices based on science process skill with direct learning model requires the preparation and management of the mature time in the implementation of its teaching-learning activity especially at the practicum activity so that the teaching and learning activities can be appropriate allocation of time provided; (2) It is necessary to conduct similar research on other biological concepts so that students are accustomed to practicing process skills because it is one of the goals in learning biology as an important aspect of Life Skills; (3) Any device that will be developed with any method or approach should not forget to insert the character and social skills. It is because the importance of noble planting can be started from within the school then be applied to daily life in the future.

\section{REFERENCES}

[1] Kementerian Pendidikan dan Kebudayaan. Kurikulum 2013: Kompetensi Dasar SMP/MTs Jakarta: Depdikbud. 2013.

[2] A.A. Carin, Teaching Modern Science Sixth Edition. New York: Merril, An Imprint of Mc.Millan Publishing Company, 1993.

[3] F. Karsli, C. Sahin, A. Ayas, "Determining Science Teachers' Ideas About The Science Process Skills: A Case Study". World Conference Education Science, Procedia Social and Behavioral Science, halaman 890-895. 2009.

[4] Suryanti, M. Ibrahim, and N.S. Lede, "Process skills approach to develop primary students' scientific literacy: A case study with low achieving students on water cycle", The Consortium of Asia-Pacific Education Universities (CAPEU), IOP Conf. Series: Materials Science and Engineering 296012030 doi:10.1088/1757-899X/296/1/012030. 2018.

[5] R.A.A. Rauf1, M.S. Rasul, A.N. Mansor, Z. Othman \& N. Lyndon, "Inculcation of Science Process Skills in a Science Classroom", Asian Social Science, Vol. 9, No. 8. 2013

[6] S. Kardi and M. Nur, Pengajaran Langsung (Surabaya: PSMS UnesaPress). 2005

[7] H. Wenno, "Direct Instruction Model to Increase Physical Science Competence of Students as One Form of Classroom Assesment", International Journal of Evaluation and Research in Education (IJERE), Vol.3, No.3, pp. 169 174, September 2014.

[8] W. Foulds and J. Rowe, "The Enhancement of Science Process Skill in Primary Teacher Education Students", Australia Journal of Teacher Education, Volume 21, no 1, halaman 16-23. Australia. 1996.

[9] S. Arikunto, Prosedur Penelitian Suatu Pendekatan Praktik. Edisi Revisi IV. Jakarta: Rineka Cipta, 2006.

[10] H.E. Abungu, M.I.O. Okere, S.W. Wachanga, "The Effect of Science Process Skills Teaching Approach on Secondary School Students' Achievement in Chemistry in Nyando District, Kenya", Journal of Educational and Social Research MCSER Publishing. Rome-Italy, Vol. 4, No.6. 2014.

[11] M.L. Ango, "Mastery of Science Process Skills and Their Effective Use In The Teaching Of Science: An Educology of Science Education In The Nigerian Context", International Journal of Educology, Vol. 16, no.1, halaman 11-30, 2002

[12] H. Tohidi, M M. Jabbari, "The effects of motivation in education", Procedia - Social and Behavioral Sciences 31, 820 - 824, 2012.

[13] R.A. Kusurkar, Th. J.T. Cate, C.M.P. Vos, P. Westers and G. Croiset, "How motivation affects academic performance: a structural equation modelling analysis", Adv in Health Sci Educ. 18:57-69. 2013.

[14] A. Rehman and K. Haider, "The Impact Of Motivation On Learning Of Secondary School Students In Karachi: An Analytical Study", Educational Research International ISSN-L: 2307-3713, Vol. ,2 No. 2,2013

[15] H. Aktamis and Ö. Ergin, "The Effect Of Science Process Skills Education On Students' Scientific Creativity, Science Attitude And Academic Achievement", Asia-Pacific Forum on Science Learning and Teaching, Vol.9 Issue 1, halaman 1-21, 2008.

[16] Haryono, "Model Pembelajaran Berbasis Peningkatan Keterampilan Proses Sains", Jurnal Pendidikan Dasar. Volume.7, No.1: Halaman 113. Solo, 2006

[17] A. Mahsul, Kualitas Hasil Belajar Siswa Melalui Pelatihan Keterampilan Proses yang Diajarkan dengan Model Direct Instruction Jurnal BIOTA, Volume 3, no.2, halaman 233-248, 2010.

[18] Haryati, B. Manurung, T. Gultom, "The Effect of Learning Model on Higher Order Thinking and Student Science Process Skills in Ecology", 
International Journal of Humanities Social Sciences and Education (IJHSSE) Volume 4, Issue 10, October 2017, PP 150-155. 2017.

[19] P.O. Yara, "Students Attitude Towards Mathematics and Academic Achievement in Some Selected Secondary Schools in Southwestern Nigeria", European Journal of Scientific Research. ISSN 1450-216X Vol.36, No.3, halaman 336-341, 2009.

[20] Suyanto, Urgensi Pendidikan Karakter. Artikel. [online]. Tersedia: http://mandikdasmen.kemdiknas.go.id/web/pages/urgensi.html download tanggal 19 november 2010). 